\title{
Cell-Specific Expression of High Levels of Human S100 $\beta$ in Transgenic Mouse Brain Is Dependent on Gene Dosage
}

\author{
William C. Friend,, ${ }^{1,2, a}$ Susan Clapoff, ${ }^{2}$ Charles Landry, ${ }^{3}$ Laurence E. Becker, ${ }^{4}$ David O’Hanlon, ${ }^{1}$ Robert J. \\ Allore, ${ }^{1}$ lan R. Brown, ${ }^{3}$ Alexander Marks, ${ }^{1}$ John Roder, ${ }^{2}$ and Robert J. Dunn ${ }^{5}$ \\ ${ }^{1}$ Banting and Best Department of Medical Research, University of Toronto, Toronto, Ontario, Canada M5G 1L6, ${ }^{2}$ Division \\ of Molecular Immunology and Neurobiology, Samuel Lunenfeld Research Institute, Mount Sinai Hospital, Toronto, Ontario, \\ Canada M5G 1X5, ${ }^{3}$ Department of Zoology, University of Toronto, Scarborough Campus, West Hill, Ontario, Canada M1C \\ 1A4, ${ }^{4}$ Department of Pathology, Hospital for Sick Children, Toronto, Ontario, Canada M5G 1X8, and ${ }^{5}$ Neurosciences Unit, \\ Montreal General Hospital Research Institute, Montreal, Quebec, Canada M3G 1A4
}

The $\beta$-subunit of $\mathbf{S} 100$ protein ( $100 \beta$ ) is highly conserved in the mammalian brain. The gene coding for human $\mathrm{S100} \beta$ has been mapped to chromosome 21 . In order to study the consequences of overexpression of the $5100 \beta$ gene, transgenic mice were generated by microinjection of a 17.3 kilobase human genomic fragment containing the three exons and the transcription control elements of the human $\$ 100 \beta$ gene. Mice from four transgenic lines carried approximately 10-100 transgene copies. Northern blotting demonstrated a tissue-specific and gene dose-dependent expression of human $\mathbf{S 1 0 0} \beta$ mRNA in mouse brain. Increased expression of $\mathbf{S 1 0 0} \beta$ mRNA was correlated with an increased production of $\mathrm{S100 \beta}$ protein. Examination of brain sections by in situ hybridization and immunocytochemistry indicated that $\mathbf{S 1 0 0} \beta$ was localized globally to astrocytes, as well as to discrete neurons in the mesencephalic and motor trigeminal, facial, and lemniscus nuclei in both normal and transgenic mice. In peripheral tissues, human $5100 \beta$ was expressed at 10-50fold lower levels than in brain. The strict gene dosage dependence and cell specificity of transgene expression suggest the presence of a locus control region (LCR) in the human $\mathrm{S100} \beta$ gene. The mice tolerated 10-100-fold higher than normal levels of $\mathbf{S 1 0 0 \beta}$ gene expression in brain without any gross physical or behavioral abnormalities. The highlevel expression and cell specificity of the $\mathbf{S 1 0 0 \beta}$ promoter/ LCR suggest that it may provide a valuable tool to direct the expression of other transgenic products to specific cell types in the CNS.

\footnotetext{
Received Dec. 23, 1991; revised May 11, 1992; accepted June 5, 1992.

We are grateful to Mr. J. Law and Mrs. M. Lei for excellent technical assistance, and to Dr. B. Boss for the monoclonal anti-S100 protein antibody. This research was supported by grants from the Medical Research Council to A.M. and R.J.D., Networks of Centres of Excellence to J.R., Natural Sciences and Engineering Research Council to I.R.B., and National Institutes of Health (USA) to L.E.B. J.R. is an MRC Scientist, and W.C.F. a Centennial Fellow, of the Medical Research Council of Canada.

Correspondence should be addressed to Dr. A. Marks, Banting and Best Department of Medical Rescarch, University of Toronto, 112 Collcge Strcet, Toronto, Ontario M5G 1L6, Canada.

a Present address: Department of Psychiatry, The University of Calgary, Calgary, Alberta, Canada T2N 2T9.

Copyright (C) 1992 Society for Neuroscience $0270-6474 / 92 / 124337-10 \$ 05.00 / 0$
}

$\mathrm{S} 100$ protein is a $20 \mathrm{kDa}$ calcium-binding protein widely distributed and conserved in the nervous system of vertebrates (Moore, 1965; Kessler et al., 1968; Calissano et al., 1969; Marks et al., 1983; Kuwano et al., 1984). It is a hetero- or homodimer of two distinct, but similar subunits, $\mathrm{S} 100 \alpha$ and $\mathrm{S} 100 \beta$, that have different tissue distributions (Isobe and Okuyama, 1978, 1981; Takahashi et al., 1984). The $\beta \beta$-form of $\mathrm{S} 100$ protein predominates in the mammalian brain, where it is found principally in the cytoplasm of astrocytes (Haan et al., 1982; Kato and Kimura, 1985; Zimmer and Van Eldik, 1987). The presence of the protein in other locations in the brain is a subject of controversy. Early studies have reported the presence of $\mathrm{S} 100$ protein in the nucleus of specific brainstem neurons (Hyden and McEwen, 1966; Sviridov et al., 1972). Later studies have disputed a neuronal location for the protein (Matus and Mughal, 1975; Ghandour et al., 1981; Haan et al., 1982).

S100 protein accumulates during the maturation of the mammalian brain (Zuckerman et al., 1970; Cicero et al., 1972; Landry et al., 1989), and participates in several calcium-dependent interactions with other brain proteins (Patel and Marangos, 1972; Zimmer and Van Eldik, 1986; Baudier and Cole, 1988). Although its localization is primarily cytoplasmic, $\mathrm{S} 100$ protein has been also detected extracellularly in the CNS, suggesting that it may exert a paracrine or autocrine function following secretion from glial cells (Shashoua et al., 1984). S100 $\beta$ has been shown to stimulate growth in glia (Selinfreund et al., 1991) and neurite extension in neurons (Kligman and Marshak, 1985; Kligman and Hsieh, 1987; Van Eldik et al., 1988; WinninghamMajor et al., 1989), in vitro. The above results have led to the suggestion that $\mathrm{S} 100 \beta$ may influence the development of the CNS by stimulating the proliferation of glia and differentiation of neurons (Marks and Allore, 1990; Selinfreund et al., 1991).

We have recently cloned and characterized the full-length human gene for $\mathrm{S} 100 \beta$ (Allore et al., 1990). This gene is composed of three exons, the first of which specifies the $5^{\prime}$ untranslated region, while the second and third each encode a single EFhand calcium-binding domain. The promoter region contains several potential regulatory elements of transcription, including cAMP-responsive elements and multiple repeats similar in sequence and location to the $\beta$-globin direct repeat elements (Allore et al., 1990). The human $\mathrm{S} 100 \beta$ gene has also been mapped to a subtelomeric location in the $21 \mathrm{q} 22.3$ region of human chro- 


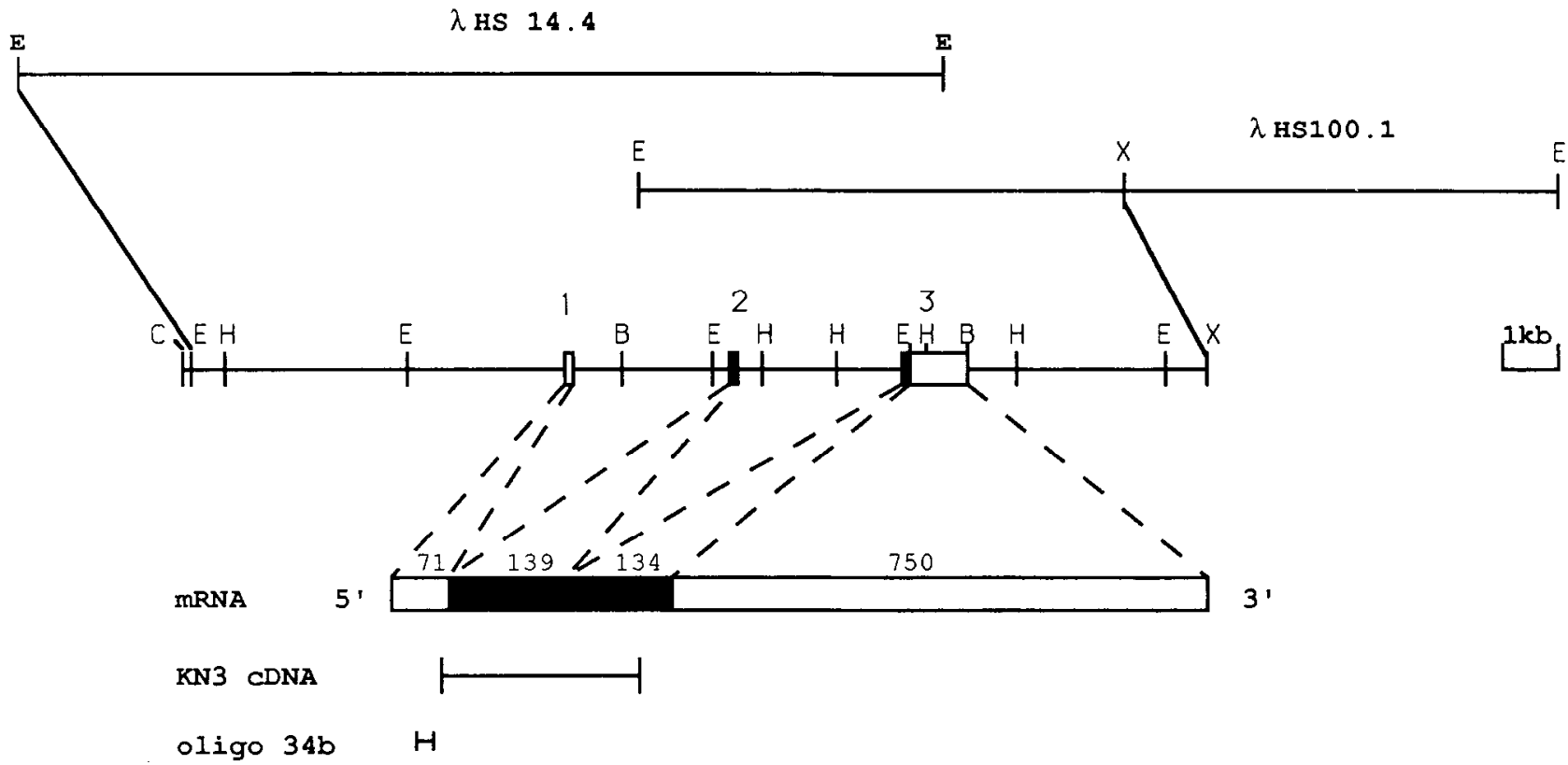

Figure 1. Schematic diagram of the $17.3 \mathrm{~kb}$ ClaI-XbaI fragment spanning the human $\mathrm{S} 100 \beta$ gene derived from genomic clones $\lambda \mathrm{HS} 14.4$ and $\lambda \mathrm{HS}$ 100.1. A partial restriction enzyme map is shown. Cleavage sites for ClaI $(C)$, EcoRI $(E)$, HindIII $(H)$, BamHI $(B)$, and XbaI $(X)$ are specified. Exons are numbered, with coding regions indicated by solid boxes and untranslated regions by open boxes. The location and size (nucleotides) of regions in mRNA corresponding to each of the three exons are shown. The regions corresponding to the probes KN3 and oligonucleotide $34 \mathrm{~b}$ are indicated.

mosome 21 (Allore et al., 1988; Duncan et al., 1989; Burmeister et al., 1991). In order to develop a model to study the developmental consequences of an increased $\mathrm{S} 100 \beta$ gene dosage, we have derived and characterized transgenic mice carrying multiple copies of the human $\mathrm{S} 100 \beta$ gene. These mice express human $\mathrm{S} 100 \beta \mathrm{mRNA}$ in a gene dose-dependent and tissue-specific manner, and higher than normal levels of $\mathrm{S} 100 \beta$ protein in brain. Furthermore, by comparing the transgenic mice with their normal (nontransgenic) littermates using in situ hybridization and immunocytochemistry, we were able to localize $\mathrm{S} 100 \beta$ precisely to astrocytes and a subset of brainstem neurons.

\section{Materials and Methods}

Transgene assembly. The transgene was derived from two overlapping human genomic clones ( $\lambda$ HS 14.4 and $\lambda$ HS 100.1) (Fig. 1) that jointly span 25 kilobases $(\mathrm{kb})$ of DNA including the $S 100 \beta$ gene (Allore et al., 1990). Nonoverlapping fragments of the two clones were subcloned in multiple steps into pBS (Stratagene) to construct plasmid pWF9c containing $17.3 \mathrm{~kb}$ of human genomic DNA. In order to excise the transgene from pWF9c, the plasmid was cut at a ClaI site situated in the $5^{\prime}$ polylinker (17 nucleotides upstream of the insert), and at a unique XbaI site situated at the $3^{\prime}$ boundary of the insert. The resulting $17.3 \mathrm{~kb}$ ClaIXbaI genomic DNA fragment consisted of $7 \mathrm{~kb}$ of DNA spanning the three exons of the human $\mathrm{S} 100 \beta$ gene and $6.3 \mathrm{~kb}$ of the upstream and $4 \mathrm{~kb}$ of the downstream sequence. The fragment was purified by ultracentrifugation through a linear $10-40 \%$ sucrose gradient, precipitated with ethanol, and redissolved in $\mathrm{H}_{2} \mathrm{O}$ (Ausubel et al., 1987).

Production of transgenic mice. The transgene was microinjected at a concentration of $1-2 \mu \mathrm{g} / \mathrm{ml}$ into male pronuclei of fertilized CD1 mouse eggs. The injected embryos surviving micromanipulation were reimplanted in the oviducts of pseudopregnant foster females, and allowed to develop to term according to published procedures (Hogan et al., 1986).

Hybridization probes. For Southern blotting, a 243 base pair partial human cDNA fragment, KN3 (encompassing most of the $\mathrm{S} 100 \beta$ coding region) (Allore et al., 1990), and an $0.8 \mathrm{~kb}$ partial rat cDNA fragment of the myelin-associated glycoprotein (MAG) (Arquint et al., 1987) were randomly labeled with $\alpha-{ }^{32} \mathrm{P}-\mathrm{dCTP}$. For Northern blotting, a ${ }^{32} \mathrm{P}-\mathrm{CTP}-$ labeled antisense riboprobe was derived from $\mathrm{KN} 3$ subcloned into an RNA synthesis vector, pBS (Stratagene), that had been linearized for in vitro transcription with BamHI. A ${ }^{32} \mathrm{P}$-CTP-labeled rat $\beta$-actin antisense riboprobe was derived as previously described (Dunn et al., 1987).

For in situ hybridization, the following ${ }^{35} \mathrm{~S}$-labeled probes were used. Antisense riboprobes labeled with ${ }^{35} \mathrm{~S}$-UTP were derived from (1) the human S100 $\beta$ cDNA clone KN3 described above, (2) a rat S100 $\beta$ cDNA clone (Dunn et al., 1987) subcloned into pSP65 (Promega) and linearized with BamHI, and (3) exon 1 of the mouse neurofilament light chain gene (Lewis and Cowan, 1986) subcloned into pGEM-3Z (Promega) and linearized with BglII. Sense riboprobes were similarly derived after linearization of the vectors with appropriate restriction enzymes. A synthetic antisense 34 base oligonucleotide, spanning the (exon 1) sequence +21 to +54 of the human S100 $\beta$ gene, was end labeled with ${ }^{35}$ S-ATP. This probe is complementary to 34 nucleotides of the $5^{\prime}$ untranslated region of the human $S 100 \beta$ mRNA.

Preparation and Southern blotting of DNA. DNA was prepared from mouse tail clippings as described in the literature (Ilogan et al., 1986). Samples of DNA $(5 \mu \mathrm{g})$ were digested with restriction enzymes, fractionated on $1 \%$ agarose gels, and blotted onto nylon membranes (Zetaprobe, Bio-Rad). Southern blotting was performed essentially as described previously (Allore et al., 1988), using a mixture of ${ }^{32} \mathrm{P}$-labeled human $\mathrm{S} 100 \beta$ and rat MAG cDNA probes. The blots were exposed to preflashed $\mathrm{x}$-ray film (Kodak X-Omat, AR) with an intensifying screen at $-70^{\circ} \mathrm{C}$. The number of human $\mathrm{S} 100 \beta$ gene copies in mice from each of the transgenic lines was determined by densitometry and comparison with a human diploid placental DNA standard. Densitometry was performed on a Molecular Dynamics computing densitometer model $300 \mathrm{~A}$ using the Molecular Dynamics IMAGE QUANT software release version 3.0 .

Preparation and Northern blotting of RNA. Mice were anesthetized and killed by ccrvical dislocation. Brain and other organs were rapidly removed, rinsed in phosphate-buffered saline (PBS; $140 \mathrm{~mm} \mathrm{NaCl}, 3$ mм KCl, $8 \mathrm{~mm} \mathrm{Na}_{2} \mathrm{HPO}_{4}, 1.5 \mathrm{~mm} \mathrm{KH}_{2} \mathrm{PO}_{4}, \mathrm{pH} 7.1$ ), frozen in liquid nitrogen, and powdered. RNA was prepared from powdered tissue by homogenization in $4 \mathrm{M}$ guanidinium isothiocyanate and centrifugation through a cushion of cesium chloride (Sambrook et al., 1989). Northern blotting was performed essentially as described previously (Dunn et al., 1987), using a ${ }^{32}$ P-labeled human $S 100 \beta$ antisense riboprobe (KN3). Blots were exposed to $\mathrm{x}$-ray film and the relative amounts of $\mathrm{S} 100 \beta$ mRNA were determined by densitometry as described above. In order 


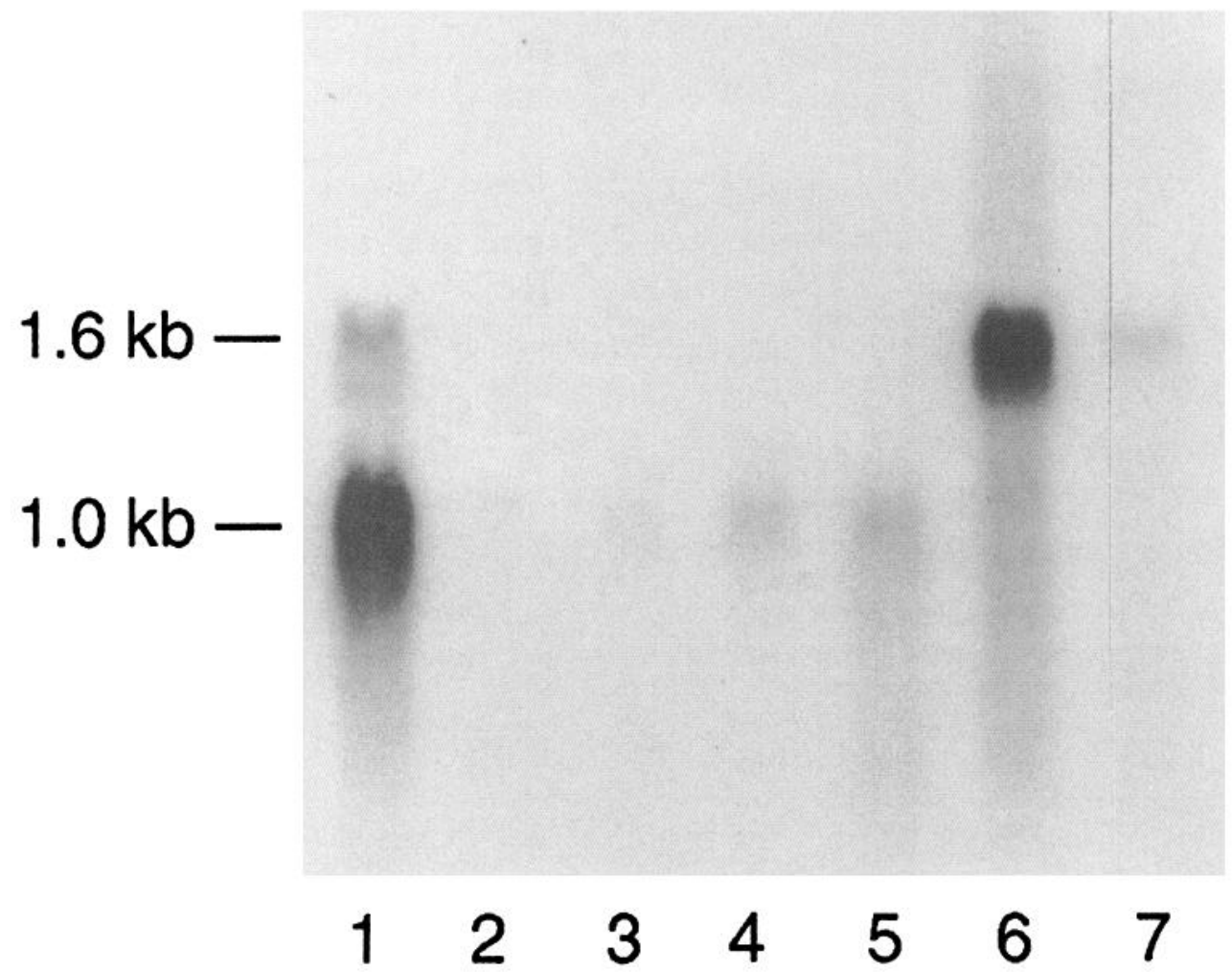

Figure 2. Tissue-specific expression of $\mathrm{S} 100 \beta$ mRNA in transgenic mice. Total RNA (10 $\mu \mathrm{g}$ per lane) was analyzed by Northern blotting, using a ${ }^{32} \mathrm{P}$ labeled human $\mathrm{S} 100 \beta$ antisense riboprobe KN3. RNA from the following sources was analyzed in the specified individual lanes: transgenic mouse (line $\mathrm{H}-2$ ) brain (1), liver (2), heart (3), kidney (4); human brain (5); rat glioma (C6) cells (6); normal mouse brain (7). The positions of migration of human S $100 \beta$ mRNA $(1.0 \mathrm{~kb})$ and mouse and rat $\mathrm{S} 100 \beta$ mRNA $(1.6 \mathrm{~kb})$ are indicated.

to control for equivalent loading of RNA, the blots were rehybridized with a ${ }^{32} \mathrm{P}$-labeled rat $\beta$-actin probe, reexposed to $\mathrm{x}$-ray film, and analyzed by densitometry.

In situ hybridization. The analysis of $15 \mu \mathrm{m}$ cryostat sections of mouse brains for expression of mouse and human $\mathrm{S} 100 \beta \mathrm{mRNA}$ and of neurofilament light chain mRNA using in situ hybridization with appropriate ${ }^{35} \mathrm{~S}$-labeled antisense riboprobes was performed as previously described (Landry et al., 1989). Alternate sections were hybridized with an equal amount of control ${ }^{35}$ S-labeled sense riboprobe. Nontransgenic littermates were used as controls for the transgenic mice.

The following modifications were instituted when the 34 base oligonucleotide probe complementary to part of the $5^{\prime}$ untranslated human S $100 \beta$ mRNA sequence was used. First, digestion of sections with proteinase $\mathrm{K}$ to facilitate probe penetration was not carried out. Second, hybridization temperature was lowered to $50^{\circ} \mathrm{C}$ from $55^{\circ} \mathrm{C}$. Third, digestion with RNase A was omitted. Fourth, the final wash in $0.1 \times$ saline-sodium citrate, $300 \mathrm{~mm} 2$-mercaptoethanol was performed at $60^{\circ} \mathrm{C}$ instead of $70^{\circ} \mathrm{C}$.

Following hybridization and washing, the sections were applied to Du Pont Cronex sensitive x-ray film or coated with Kodak NTB2 liquid emulsion, and exposed for varying periods of time. The slides were developed in Kodak D19 developer for $2.5 \mathrm{~min}$ and stained lightly with cresyl violet.

Western blotting of brain extracts for SI00ß protein. Mouse brains were obtained as described above. Brain extracts were prepared from frozen brain powder as described previously (Marks et al., 1983), except that 2-mercaptoethanol was omitted from all buffers, and assayed for protein concentration (Lowry et al., 1951). Aliquots of the $100,000 \times$ $g$ supernatants were dissociated by boiling in the presence of $2 \%$ SDS, $5 \%$ 2-mercaptoethanol and subjected to electrophoresis in $12.5 \%$ polyacrylamide slab gels in the presence of $0.1 \%$ SDS and $2 \mathrm{~mm}$ EDTA. The gels were frozen at $-70^{\circ} \mathrm{C}$ and soaked in transfer buffer $(12.5 \mathrm{~mm}$ Tris $\mathrm{HCl}, 96 \mathrm{~mm}$ glycine) for $30 \mathrm{~min}$ to remove the SDS, and the proteins were transferred electrophoretically to polyvinyl membranes (Immobilon-P, Millipore). The blots were incubated at room temperature, first for $2 \mathrm{hr}$ with PBS containing $10 \%$ skim milk to block nonspecific binding of antibody, and then for $1 \mathrm{hr}$ with anti-S100 protein monoclonal antibody G12.B8 (Haan et al., 1982; a generous gift from Dr. B. Boss, Salk Institute) at a 1:2000 dilution in PBS containing 1\% skim milk, and finally washed three times for $30 \mathrm{~min}$ each with PBS containing $0.02 \%$ Tween 20 . Following washing, the blots were incubated for $1 \mathrm{hr}$ at room temperature with peroxidase-conjugated rabbit anti-mouse Ig antibody (Dako; 1:500 dilution) and washed as described above, and the peroxidase color reaction was developed by addition of substrate ( $1 \%$ diaminobenzidine in PBS containing $0.009 \% \mathrm{H}_{2} \mathrm{O}_{2}$ for $1-2 \mathrm{~min}$ ). After visualization of the $\mathrm{S} 100 \beta$ band, the membranes were incubated with ${ }^{125} \mathrm{I}$-protein A $\left(2 \times 10^{5} \mathrm{cpm} / \mathrm{ml}\right.$ in PBS containing $1 \%$ skim milk $)$ for $2 \mathrm{hr}$ at room temperature, washed as described above, and analyzed by autoradiography as described above for Southern blotting.

Immunohistochemistry. Immunoperoxidase staining of mouse brain, liver, heart, and kidney sections for localization of $\mathrm{S} 100 \beta$ was performed as previously described (Kahn et al., 1983; Nakamura et al., 1983), except that an indirect immunoperoxidase technique was used. The organs were fixed in $10 \%$ formalin, embedded in paraffin, and cut at 6 $\mu \mathrm{m}$ sections. The sections were deparaffinized with xylol, washed in three changes of absolute ethanol, and incubated with $0.3 \% \mathrm{H}_{2} \mathrm{O}_{2}$ in methanol to inactivate endogenous peroxidase. Incubations with various sera and antisera were at room temperature in a humidified chamber. Between each incubation, the sections were washed with $5 \mathrm{~mm}$ Tris $\mathrm{HCl}, \mathrm{pH} 7.4$, containing $145 \mathrm{~mm} \mathrm{NaCl}$ (TBS). Normal swine serum was applied at a 1:10 dilution in TBS for $10 \mathrm{~min}$, followed by rabbit antiS100 protein antibody (Labourdette and Marks, 1975) at a 1:400 dilution or rabbit anti-neuron-specific enolase antibody (Dako) at a 1:250 dilution, for $60 \mathrm{~min}$. The rabbit anti-S100 protein antibody reacts with S100 $\beta$ but not $\mathrm{S} 100 \alpha$ (Kahn et al., 1991). Secondary antibody (peroxidase-conjugated swine anti-rabbit Ig antibody at a 1:20 dilution) was applied for $30 \mathrm{~min}$. The peroxidase color reaction was developed by the addition of $0.05 \%$ diaminobenzidine and $0.02 \% \mathrm{H}_{2} \mathrm{O}_{2}$ in TBS for 5 $\min$. The sections were counterstained with hematoxylin, dehydrated, cleared, and mounted.

\section{Results}

\section{Generation of transgenic mice}

The transgene consisted of a $17.3 \mathrm{~kb}$ human genomic DNA ClaI-XbaI fragment containing the three exons of the $\mathrm{S} 100 \beta$ gene, $6.3 \mathrm{~kb}$ of DNA $5^{\prime}$ to the transcription initiation site, and $4 \mathrm{~kb}$ of DNA $3^{\prime}$ to the polyadenylation signal (Fig. 1). Previous studies have demonstrated that this fragment contains the control elements required for accurate transcription of the human $\mathrm{S} 100 \beta$ gene in transfected rat glioma cells (Allore et al., 1990). 
Table 1. Relative expression of human $\mathrm{S} 100 \boldsymbol{\beta} \mathrm{mRNA}$ in organs of transgenic mice

\begin{tabular}{lcccc}
\multicolumn{5}{c}{ Transgenic line } \\
\cline { 2 - 5 } & H-2 & H-8 & H-5 & H-4 \\
\hline Brain & 100 & 100 & 100 & 100 \\
Liver & 6 & 3.2 & 3.2 & 1.7 \\
Heart & 3 & 6 & 4.4 & 6.9 \\
Kidney & 10.5 & 9 & 9.8 & 3.2
\end{tabular}

Values for human S100 $\beta$ mRNA were obtained from densitometry of Northern blots, and are expressed as relative amounts to the value obtained for brain, which was arbitrarily set at 100 . Results shown are averages of two determinations performed on one mouse from each transgenic line.

The fragment was injected into male pronuclei of fertilized CD1 mouse eggs, and the surviving embryos were reimplanted in the oviducts of pseudopregnant foster females and allowed to develop to term. Offspring were screened for transgene incorporation by Southern blotting of tail DNA with a human $\mathrm{S} 100 \beta$ specific probe. Eight founder transgenics, three males and five females, were identified. One founder male died 3 weeks after birth. Of the remaining founder mice, one of two males and two of five females failed to transmit the transgene to the F1 progeny, suggesting that these mice were mosaics that had not incorporated the transgene into the germline. The other male and three females were successfully crossed with $\mathrm{CD} 1$ mice to generate four transgenic lines $\mathrm{H}-2, \mathrm{H}-8, \mathrm{H}-5$, and $\mathrm{H}-4$. Mice from these lines carried approximately $110,70,8$, and 10 copies of the transgene, respectively (see below).

\section{Tissue-specific expression of $S 100 \beta \mathrm{mRNA}$ in transgenic mice}

On Northern blots, the human $\mathrm{S} 100 \beta$ antisense riboprobe $\mathrm{KN} 3$, which covers the evolutionarily conserved $\mathrm{S} 100 \beta$ coding sequence, hybridized to the human $\mathrm{S} 100 \beta$ mRNA of $1.0 \mathrm{~kb}$ and the mouse and rat $\mathrm{S} 100 \beta$ mRNAs of $1.6 \mathrm{~kb}$ (Fig. 2) in agreement with the sizes of human and rat $\mathrm{S} 100 \beta$ mRNA species that have been reported previously (Dunn et al., 1987; Marks et al., 1990). The size difference between the human and mouse $S 100 \beta$ mRNA species allowed identification of transcripts from the human $\mathrm{S} 100 \beta$ transgene in the presence of the endogenous cross-hybridizing mouse transcript. Both the $1.0 \mathrm{~kb}$ and $1.6 \mathrm{~kb}$ mRNA species were present in transgenic mouse brain. The human $\mathrm{S} 100 \beta$ mRNA $(1.0 \mathrm{~kb})$ was present in high amounts in brain and was detected in only very low amounts (10-50-fold less) in liver, heart, and kidney. The endogenous mouse mRNA (1.6 $\mathrm{kb}$ ) was present in brain but was not detected in liver, heart, or kidney. The relative amounts of human $\mathrm{S} 100 \beta$ mRNA present in the brain, liver, heart, and kidney in each of the transgenic cell lines are shown in Table 1. On immunoperoxidase staining, there was no $\mathrm{S} 100 \beta$ immunoreactivity in the parenchymal cells of liver, heart, and kidney. A small number of S100 $\beta$-immu-
Figure 3. Analysis of the human $\mathrm{S} 100 \beta$ gene and its products in transgenic mice. $A$, Southern blotting was performed on EcoRI-digested samples of DNA ( $5 \mu \mathrm{g}$ per lane), using a mixture of ${ }^{32} \mathrm{P}$-labeled rat MAG and human $\mathrm{S} 100 \beta$ cDNA probes. The position of the genomic EcoRI fragments that hybridize to the rat MAG $(4.4 \mathrm{~kb})$ and human $\mathrm{S} 100 \beta$ $(3.2 \mathrm{~kb}) \mathrm{cDNA}$ probes are indicated. $B$, Northern blotting of total brain RNA (5 $\mu \mathrm{g}$ per lane) using a ${ }^{32} \mathrm{P}$-labeled human $\mathrm{S} 100 \beta$ antisense riboprobe $\mathrm{KN} 3$. The blots were exposed to x-ray film for $5 \mathrm{~d}$ at $-70^{\circ} \mathrm{C}$. The blots were rehybridized with a ${ }^{32} \mathrm{P}$-labeled rat $\beta$-actin antisense probe, and reexposed to $\mathrm{x}$-ray film for $20 \mathrm{hr}$. $B$ is a composite of the two autoradiograms. The positions of migration of mouse $\beta$-actin mRNA (1.8 kb), mouse S100 $\beta$ mRNA $(1.6 \mathrm{~kb})$, and human $S 100 \beta$ mRNA (1.0 kb) are indicated. $C$, Western blotting was performed on brain extracts $(4 \mu \mathrm{g} /$ lane) following separation by SDSPAGE under reducing conditions. The primary antibody used was mouse monoclonal anti-S100 protein antibody, followed by rabbit anti-mouse $\mathrm{Ig}$ antibody, and ${ }^{125}$ I-protein A. The position of migration of $\mathrm{S} 100 \beta$ protein $\left(M_{r}\right.$ $10 \mathrm{~K})$ is indicated. The origin of the DNA, RNA, and protein samples in the respective lanes is the following: transgenic lines $\mathrm{H}-2$ (lanes 1 and 2 ), $\mathrm{H}-8$ (lanes 3 and 4), H-5 (lanes 5 and 6), H-4 (lanes 7 and 8 ), control (nontransgenic) mouse (lane 9), human (lane 10). DNA, RNA, and protein samples were from the same individual mouse in each of the respective lanes 1-9.
(A) DNA



(B) RNA

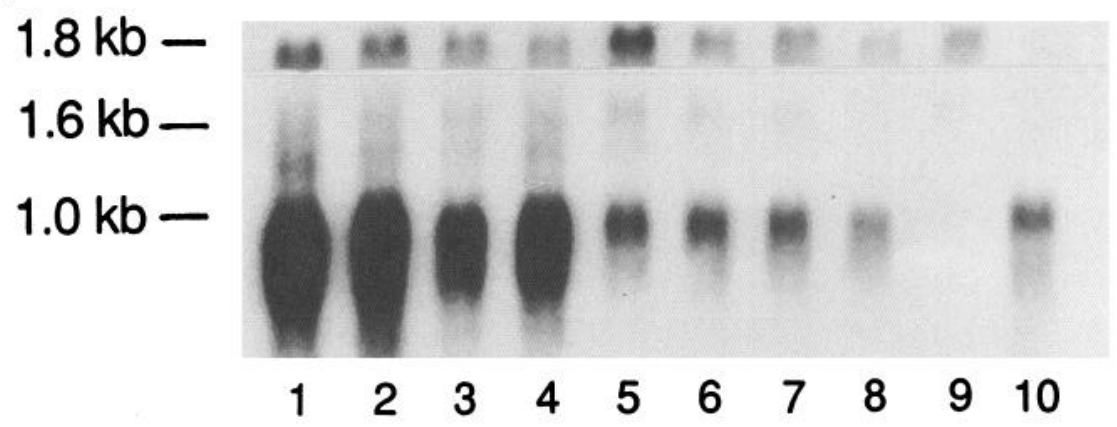

(C) Protein
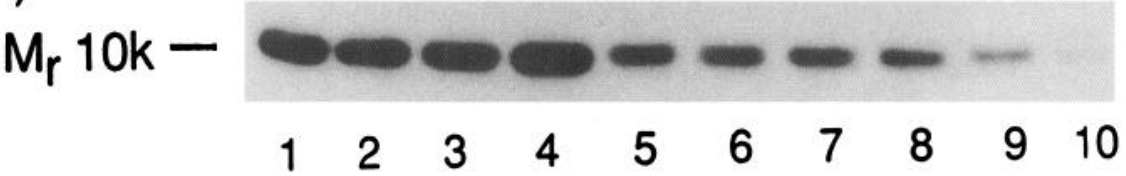
noreactive histiocytes were seen (data not shown). Other minor cell types that likely contribute to the low level of human $\mathrm{S} 100 \beta$ mRNA expression in these organs include Schwann cells that surround the innervating nerve fibers (Kahn et al., 1991). The precise localization of $\mathrm{S} 100 \beta$ in cell types outside the CNS is presently under investigation in the transgenic mouse lines.

\section{Dosage-dependent expression of the human $S 100 \beta$ gene in transgenic mice}

The results of Southern blot analysis of tail DNA, Northern blot analysis of brain RNA, and Western blot analysis of brain extracts of mice from each of four transgenic lines are shown in Figure 3. On Southern blotting (Fig. 3A), the rat MAG and human $\mathrm{S} 100 \beta$ cDNA probes hybridized to $4.4 \mathrm{~kb}$ and $3.2 \mathrm{~kb}$ EcoRI fragments, respectively. At the stringency conditions used, the human $\mathrm{S} 100 \beta$ cDNA probe hybridized to human placental DNA (Fig. 3A, lane 10) but not to control (nontransgenic) mouse DNA (lane 9). The signal obtained with the MAG probe was used to correct for loading differences in the DNA samples from the transgenic mice for estimation of gene copy number from densitometric analysis.

On Northern blotting (Fig. $3 B$ ), the rat $\beta$-actin antisense probe hybridized to a $1.8 \mathrm{~kb}$ mRNA species, and the human $\mathrm{S} 100 \beta$ (KN3) antisense probe, to a $1.6 \mathrm{~kb}$ mouse $\mathrm{S} 100 \beta \mathrm{mRNA}$ and a $1.0 \mathrm{~kb}$ human $\mathrm{S} 100 \beta$ mRNA species. Both $S 100 \beta$ mRNA species were present in transgenic mouse brain. The human $S 100 \beta$ mRNA signal was much stronger than the mouse S100 $\beta$ mRNA signal. In addition, a minor hybridizing band was also seen below the mouse $\mathrm{S} 100 \beta \mathrm{mRNA}$ in the high transgene copy lines $\mathrm{H}-2$ and $\mathrm{H}-8$ (Fig. $3 B$, lanes $1-4$ ). This band likely represents a minor transcript of the human $\mathrm{S} 100 \beta$ transgene. The signal obtained with the actin probe was used to correct for the loading differences in the RNA from the transgenic mice for estimation of relative amounts of $\mathrm{S} 100 \beta$ mRNA from densitometric analysis. The strength of the human $S 100 \beta$ mRNA signal on Northern blots increased in parallel with the human $\mathrm{S} 100 \beta$ gene signal on Southern blots, suggesting a direct correlation between human $\mathrm{S} 100 \beta$ gene copy number and the amount of human $\mathrm{S} 100 \beta$ mRNA in the brain of mice from each of the four transgenic lines. In contrast, the mouse $\mathrm{S} 100 \beta$ mRNA signal did not vary appreciably among the brains of these mice. On the basis of densitometric analysis, the mean amount of mouse $S 100 \beta$ mRNA in the brain of the eight transgenic mice shown in Figure $3 B$ represented $0.14 \pm 0.05( \pm \mathrm{SD})$ of the amount of human $\mathrm{S} 100 \beta$ mRNA in the brain of transgenic mice with the lowest human $\mathrm{S} 100 \beta$ gene copy number (line $\mathrm{H}-5$ ). This correlates well with the average number of human transgene copies (eight) present in this cell line.

On Western blotting (Fig. 3C), S100 $\beta$ protein from transgenic mouse, normal mouse, and human brain migrated with an $M_{r}$ of 10,000 in SDS-PAGE under reducing conditions, in the same position as that of the subunits of purified bovine brain $\mathrm{S} 100$ protein (not shown). In general, there was good agreement between the strengths of the $S 100 \beta$ mRNA signal on Northern blots and the corresponding $S 100 \beta$ protein signal on Western blots for individual mice from the four transgenic lines, suggesting a direct correlation between levels of human $\mathrm{S} 100 \beta$ mRNA and the corresponding levels of the translated protein.

The relationship between transgene copy number and levels of human S100 $\beta$ mRNA in the four transgenic lines is shown in Figure 4. The levels of human $S 100 \beta$ mRNA increased directly with increased transgene copy number.

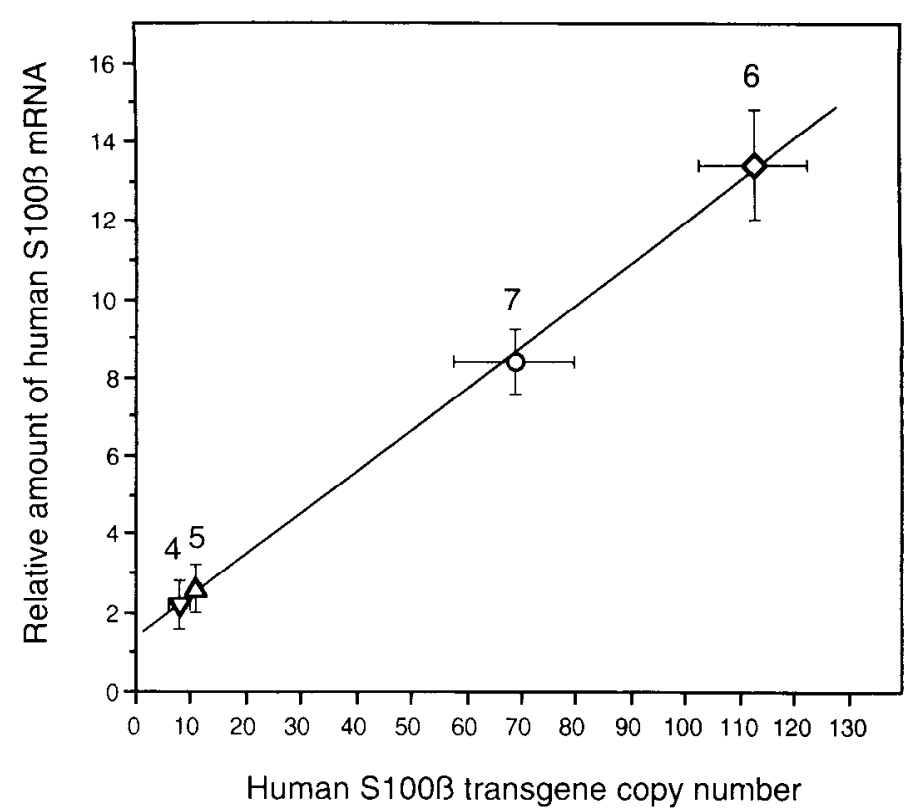

Figure 4. Gene dosage-dependent expression of human S100 3 mRNA in transgenic mouse brain. Gene copy numbers of the human $\mathrm{S} 100 \beta$ transgene were determined by densitometric analysis of Southern blots of tail DNA of transgenic mice (Fig. $3 A$ ) and comparison with a human diploid DNA standard as described in Materials and Methods. The amounts of the human $\$ 100 \beta$ mRNA were obtained by densitometric analysis of Northern blots of brain RNA (Fig. 3B) as described in Materials and Methods and are expressed as relative amounts to the lowest value obtained for a transgenic mouse (from line H-5) that was arbitrarily set at 1.0. The means of the relative amounts of $S 100 \beta$ mRNA are plotted against the means of the human $S 100 \beta$ transgene copy numbers for lines $\mathrm{H}-2(\diamond), \mathrm{H}-8(O), \mathrm{H}-4(\triangle)$, and $\mathrm{H}-5(\nabla)$. Vertical and horizontal error bars represent \pm SEM for relative amount of $\mathrm{S} 100 \beta$ mRNA and transgene copy number, respectively, and the number of individual mice analyzed is shown above each point. All mice analyzed were approximately 1.4 years of age. No variations were observed between male and female mice.

\section{Regional distribution of $S 100 \beta m R N A$ in normal and transgenic mouse brain determined by in situ hybridization}

Brain regions that express $\mathrm{S} 100 \beta$ mRNA were identified by in situ hybridization (Fig. 5) using a rat $\mathrm{S} 100 \beta$ antisense riboprobe in normal mice (Fig. 5A,D,G), and a 34 base human antisense oligonucleotide probe complementary to part of the $5^{\prime}$ untranslatcd region of human $\mathrm{S} 100 \beta$ mRNA in transgenic mice (Fig. $5 B, E, H)$. The oligonucleotide probe was specific for human $\mathrm{S} 100 \beta$ mRNA and did not hybridize with mouse mRNA in normal mouse brain (Fig. $5 C, F, I$ ). The distribution of mouse and human $\mathrm{S} 100 \beta \mathrm{mRNA}$ in normal and transgenic mouse brain, respectively, was remarkably similar. At low magnification (Fig. $5 A, B$ ), S $100 \beta$ mRNA was found to be concentrated in specific brain regions such as cerebellum and defined brainstem nuclei including the mesencephalic and motor trigeminal, facial, and lemniscus. Focusing on the cerebellum at higher magnification (using dark-field microscopy) (Fig. $5 D, E$ ), $\mathrm{S} 100 \beta$ mRNA was found in the molecular cell layer and deep white matter, but not in the granule cell layer. At a still higher magnification of the Purkinje cell layer (Fig. $5 G, H$ ), the signal corresponding to $\mathrm{S} 100 \beta \mathrm{mRNA}$ was localized over Bergmann glia situated between Purkinje neurons. This localization was particularly well defined in the transgenic mouse brain because of the high amount of the human $\mathrm{S} 100 \beta$ mRNA (Fig. $5 H$ ). 

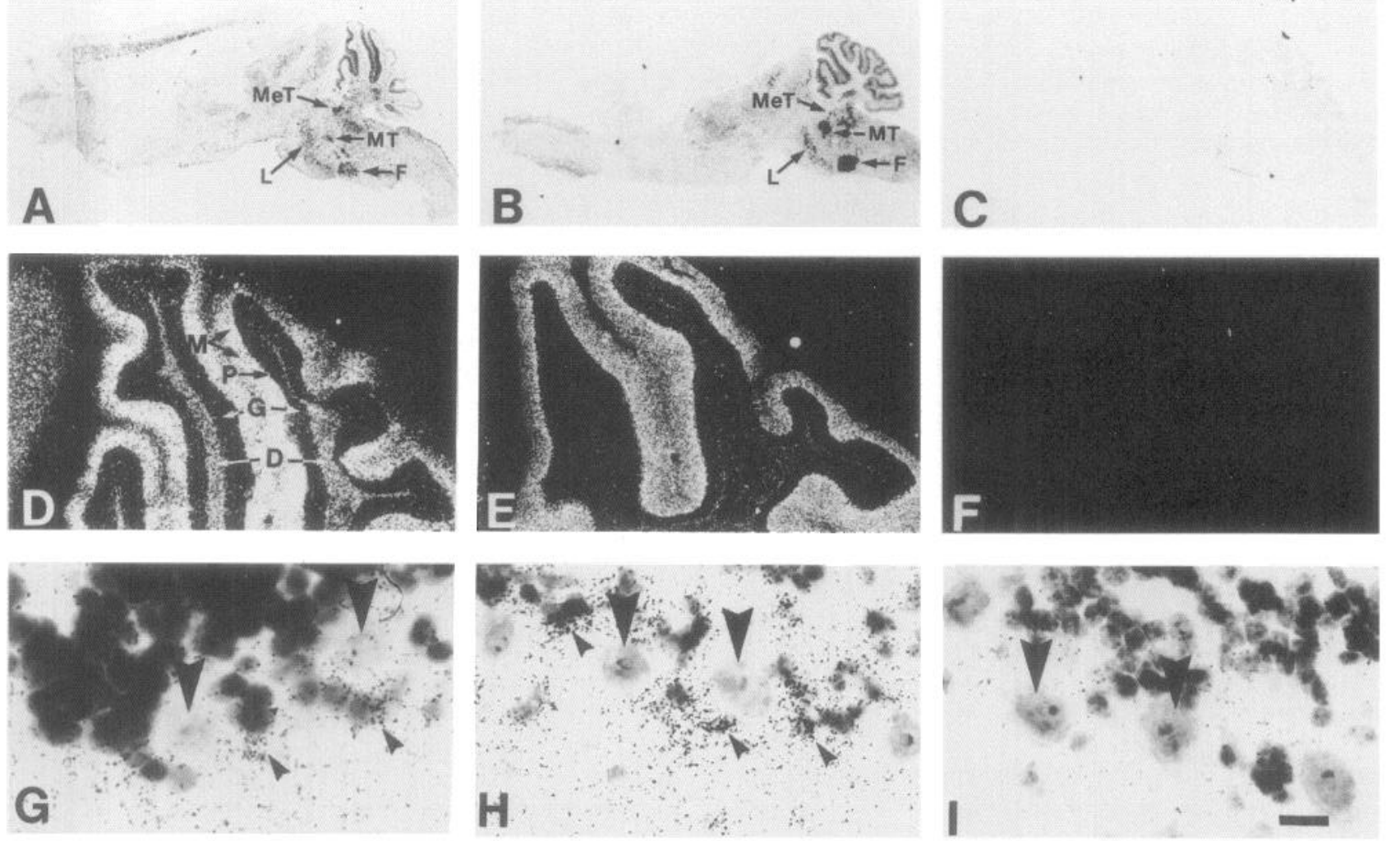

Figure 5. Distribution of $\mathrm{S} 100 \beta$ mRNA in normal and transgenic mouse brain determined by in situ hybridization. Saggital sections of brain from normal and transgenic (line $\mathrm{H}-2$ ) mice were hybridized in situ using ${ }^{35} \mathrm{~S}$-labeled antisense probes specific for mouse and human S100 $\beta$ mRNA respectively. The origins of the DNA, RNA, and protein samples in the respective lanes are the following: $A, D$, and $G$, normal mouse hybridized with a rat $\mathrm{S} 100 \beta$ antisense riboprobe; $B, E$, and $H$, transgenic mouse hybridized with a 34 base oligonucleotide probe complementary to the untranslated region of human $\mathrm{S} 100 \beta \mathrm{mRNA} ; C, F$, and $I$, normal mouse hybridized with the human oligonucleotide probe. $A-C$, Sections analyzed by autoradiography following exposure to $\mathrm{x}$-ray film, showing specific hybridizing brain regions: cerebellum and brainstem nuclei including motor trigeminal $(M T)$, mesencephalic trigeminal $(M e T)$, facial $(F)$, and lemniscus $(L) . D-F$, Dark field of emulsion-coated slides, low magnification, showing specific hybridizing cell layers of cerebellum: molecular $(M)$, Purkinje $(P)$, granule $(G)$, deep white matter $(D)$. $G-I$, Bright field of emulsioncoated slides, high magnification of Purkinje cell layer showing Purkinje neurons (large arrowheads) and Bergmann glia (small arrowheads). Exposure times: transgenic mouse: $B-3 \mathrm{~d}, E, H-10 \mathrm{~d}$; normal mouse, $A, D, G$ and $C, F, I-30 \mathrm{~d}$. Scale bar: $A-C, 2 \mathrm{~mm} ; D-F, 500 \mu \mathrm{m} ; G-I, 10 \mu \mathrm{m}$.

\section{Expression of $S 100 \beta \mathrm{mRNA}$ and protein in discrete neuronal populations}

In order to examine the possibility that $\mathrm{S} 100 \beta$ mRNA was expressed in discrete neuronal populations in brainstem nuclei, the pattern of hybridization obtained using a neuronal marker probe (mouse neurofilament light chain antisense riboprobe) was compared with that obtained using the rat $\mathrm{S} 100 \beta$ antisense riboprobe (Fig. 6). In normal mice, the patterns were very similar over the trigeminal and facial nuclei (Fig. 6A,B). When consecutive sections of the mesencephalic trigeminal nucleus were probed with the $\mathrm{S} 100 \beta$ (Fig. 6C) or neurofilament (Fig. $6 D)$ probes, the signals appeared to be localized over identical cells, suggesting that discrete brainstem neurons express $\mathrm{S} 100 \beta$ mRNA. Likewise, in transgenic mice, the pattern of labeling over the facial nucleus in a section hybridized with the human $\mathrm{S} 100 \beta$ antisense riboprobe (KN3) (Fig. $6 E$ ), was very similar to that in an adjacent section hybridized with the neurofilament probe (Fig. $6 F$ ). At the stringency conditions used for in situ hybridization, $\mathrm{KN} 3$ did not hybridize to sections of normal mouse brain (Fig. $6 G, H$ ). There was no hybridization signal above background with any of the control sense riboprobes.

In order to correlate regional and cellular expression of $\mathrm{S} 100 \beta$ mRNA with protein, sections of normal and transgenic mouse brain were examined for the presence of $\mathrm{S} 100 \beta$ protein by immunoperoxidase staining using a rabbit anti-S100 protein polyclonal antibody (Fig. 7). In all regions and cell types examined, staining was more intense in transgenic mice (Fig. $7 B, D, F$ ), than in normal mice $(A, C, E) . \mathrm{S} 100 \beta$ protein was present in individual astrocytes in hippocampus (Fig. $7 A, B$ ), in Bergmann glia between Purkinje neurons in cerebellum (Fig. $7 C, D$ ), and discrete neurons in brainstem (Fig. $7 E, F$ ). In normal mice, positive staining was confined to the nucleus of selected brainstem neurons. In the same regions of brainstem in transgenic mice, staining was of much greater intensity and involved both the nucleus and cytoplasm of neurons. Additional confirmation of the neuronal cell type was provided by Bielschowsky staining (Fig. $7 G$ ) and positive immunoperoxidase staining with antibody to neuron-specific enolase (Fig. $7 \mathrm{H}$ ), but absence of staining with antiglial fibrillary acidic protein antibody (not shown).

The agreement between the results of in situ hybridization and immunoperoxidase staining indicates a concordance between expression of $\mathrm{S} 100 \beta$ mRNA and production of $\mathrm{S} 100 \beta$ protein, suggesting that the protein is synthesized in the cells where it is found and not taken up after secretion from other sources. Moreover, the pattern of increased S100 $\beta$ immunoreactivity in astrocytes and neurons was similar in brains of mice from each of the four transgenic lines, indicating that there 

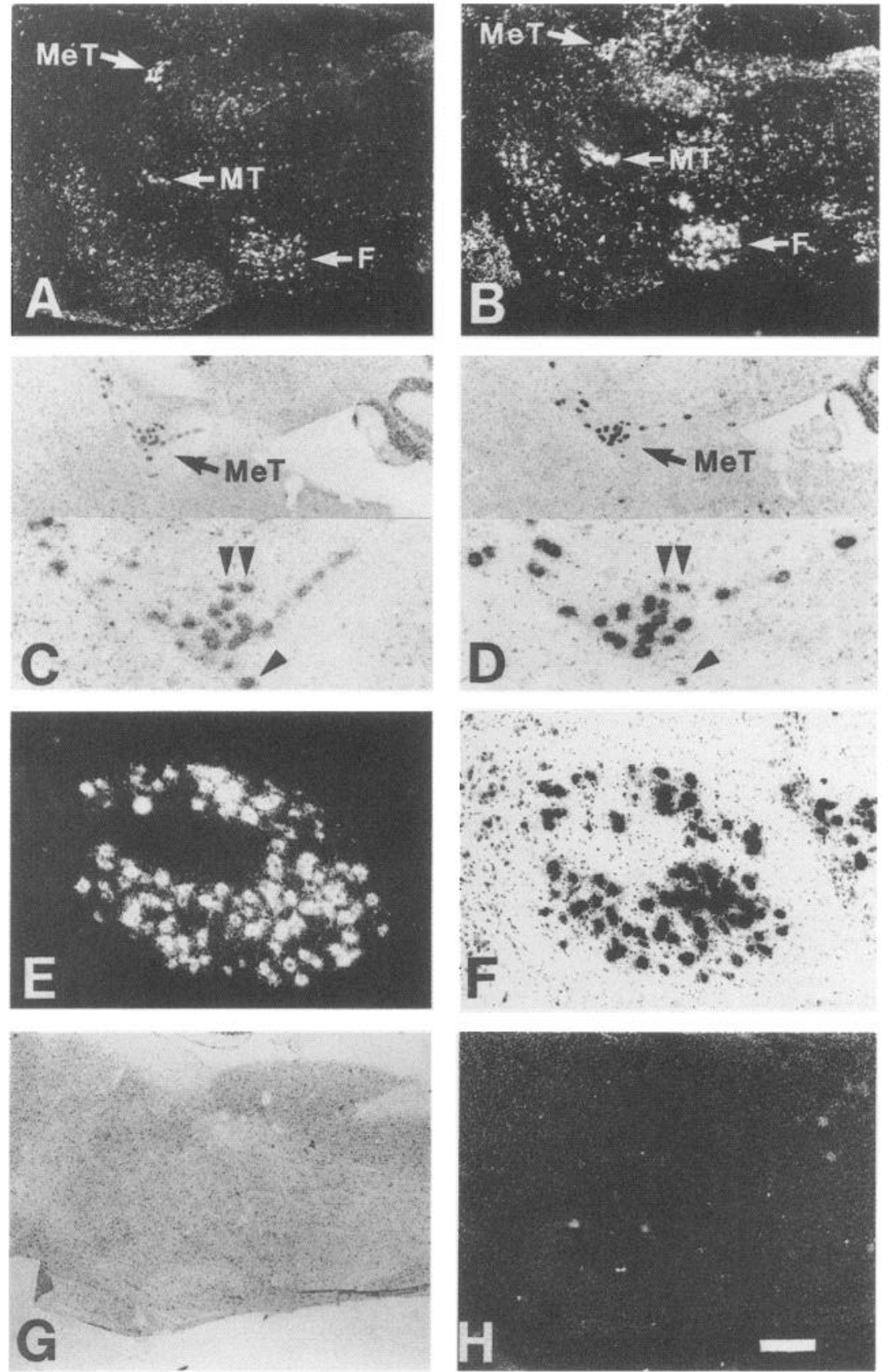

Figure 6. Localization of $\mathrm{S} 100 \beta$ mRNA in neurons by in situ hybridization. Saggital sections of brain from normal and transgenic (line $\mathrm{H}-2$ ) mice were hybridized in situ using ${ }^{35} \mathrm{~S}$-labeled antisense riboprobes specific for rat and human $\mathrm{S} 100 \beta$ mRNA, and mouse neurofilament light chain mRNA. $A-D$, Normal mouse hybridized with rat $\mathrm{S} 100 \beta$ antisense riboprobe $(A, C)$, and neurofilament antisense riboprobe $(B, D)$. Brainstem nuclei, mesencephalic trigeminal $(M e T)$, motor trigeminal $(M T)$, and facial $(F)$, are indicated. $C$ and $D$ (lower half), Enlargement of in situ hybridization to consecutive sections of the mesencephalic trigeminal nucleus; arrowheads indicate identical neurons showing positive hybridization signal with rat $\mathrm{S} 100 \beta$ antisense riboprobe $(C)$, and neurofilament antisense riboprobe (D). $E$ and $F$ Consecutive sections of the facial nucleus in transgenic mouse brain, hybridized with a human $\mathrm{S} 100 \beta$ antisense riboprobe $(\mathrm{KN} 3)(E)$, and a neurofilament antisense riboprobe $(F) . G$ and $H$, Normal mouse hybridized with the human $\mathrm{S} 100 \beta$ probe. $A, B, E$, and $H$, dark field; $C, D, F$, and $G$, bright field. Slides were coated with Kodak NTB2 emulsion, and exposed for the following times: $A$ and $C, 30 \mathrm{~d} ; B$ and $D-H, 21$ d. Scale bar: $A, B, G$, and $H, 400 \mu \mathrm{m}$; $C$ and $D$, top, $200 \mu \mathrm{m} ; C$ and $D$, bottom, and $E$ and $F, 100 \mu \mathrm{m}$.

was no extinction of specific expression of human $\mathrm{S} 100 \beta$ in any of the gene-positive progeny.

\section{Discussion}

Presence of a locus control region in the human $S 100 \beta$ gene In many transgenic mouse studies, expression from the inserted transgene has been found to vary among lines derived from different founder animals. In addition, expression from the transgene often did not correlate with the transgene copy number and was at a much lower level than expression from the endogenous homolog (Palmiter and Brinster, 1986). These quantitative differences are believed to reflect a position effect resulting from random integration of the transgene into the mouse genome (Palmiter and Brinster, 1986). Locus control regions (LCRs) (Stamatoyannopoulos, 1991) that circumvent these limitations have been identified in the flanking regions of a number of human genes including $\beta$-globin and CD2 (Grosveld et al., 1987; Greaves et al., 1989). Similarly, introduction of the 17.3 $\mathrm{kb} \mathrm{S} 100 \beta$ gene fragment into transgenic mice resulted in a position-independent, copy number-dependent, expression of both $\mathrm{S} 100 \beta$ mRNA and S100 $\beta$ protein. Even though gene expression increased to levels 10-100-fold above normal, tissue and cell specificity were maintained. Expression of human S100 $\beta$ mRNA in liver, heart, and kidney was detected at levels 10-50-fold lower than that observed in brain, and there was no $\mathrm{S} 100 \beta$ immunoreactivity in the parenchymal cells in any of these (nonbrain) organs. These results suggest that a sequence within the $17.3 \mathrm{~kb}$ fragment functions as an LCR in a manner analogous to the LCR described for the human $\beta$-globin gene (Grosveld et al., 1987). The $\beta$-globin LCR has been shown to activate both $\beta$-globin and heterologous genes in transgenic mice in a gene copy-dependent, erythroid-specific manner, independent of the 
Figure 7. Immunohistochemical localization of $\mathrm{S} 100 \beta$ protein in normal and transgenic mouse brain. Saggital sections of brains from normal $(A, C$, $E)$ and transgenic $(B, D, F)$ mice were stained with rabbit anti-S100 protein antibody using the immunoperoxidase reaction. $A$ and $B$, hippocampus; $C$ and $D$, cerebellum; $E$ and $F$, brainstem. $B$, $D$, and $F$ show increased immunoreactivity ( $B$ and $D$ within astrocytes, and $F$ within neurons). In $E$, immunoreactivity is confined to neuronal nuclei, and in $F$, it is present in both neuronal nuclei and cytoplasm. $G$ and $H$ are brainstem regions of a normal mouse showing neurons stained with Bielschowsky stain $(G)$ or with rabbit anti-neuronspecific enolase antibody $(H)$. Scale bar: $A-D, 200 \mu \mathrm{m} ; E-H, 100 \mu \mathrm{m}$.
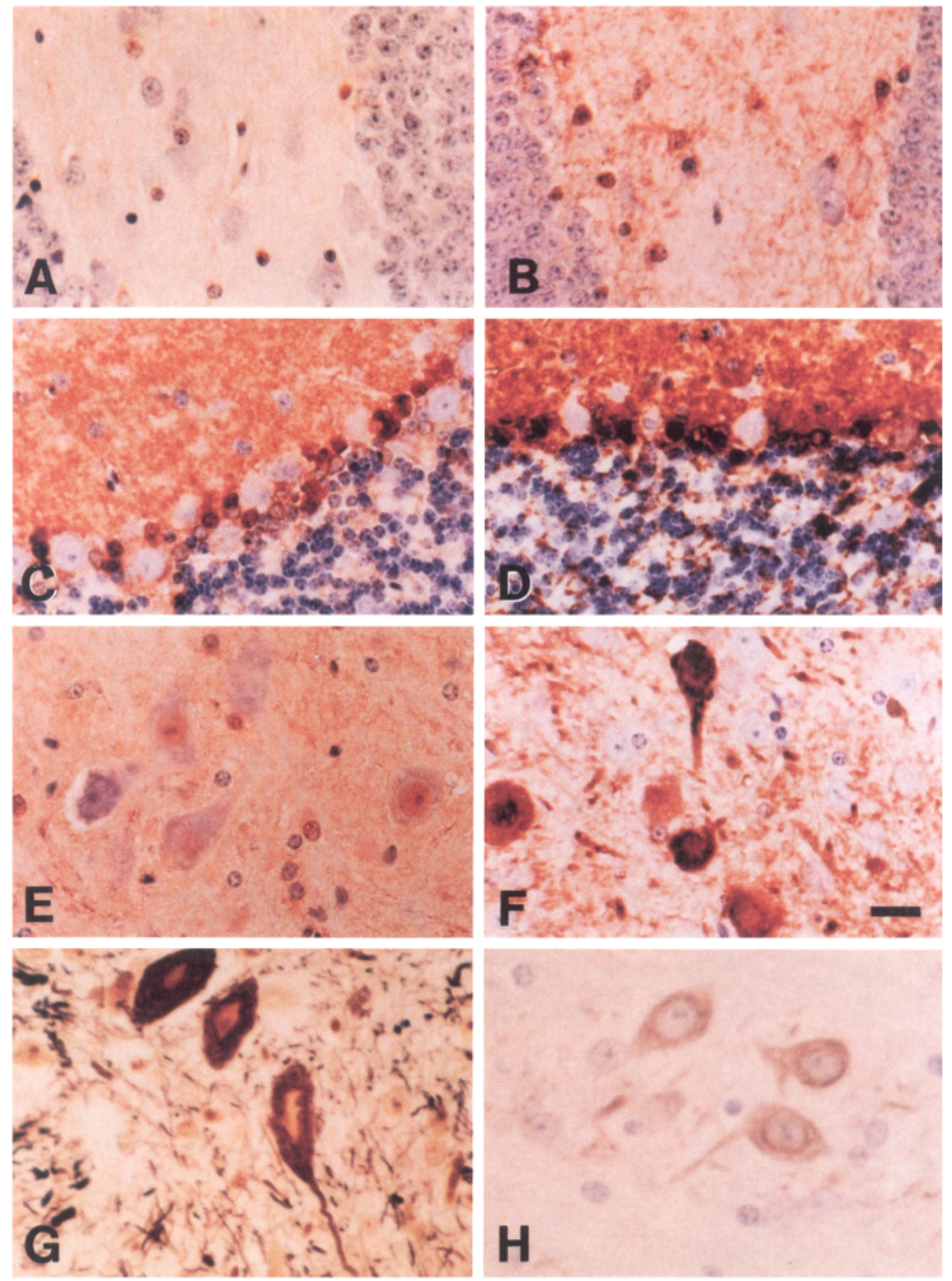

site of transgene insertion (Grosveld et al., 1987; Blom van Assendelft et al., 1989). These unique gene-regulating properties appear to be due to two activities of the globin LCR, a chromatin domain organizing activity indicated by the appearance of DNase I-sensitive regions, and a transcription enhancer activity (Behringer et al., 1990; Collis et al., 1990). A similar activity, manifested in the CNS, particularly in astrocytes and selected brainstem neurons, appears to reside in the $\mathrm{S} 100 \beta$ gene fragment studied here. Sites of DNase I sensitivity may provide useful markers for the location of the $\mathrm{S} 100 \beta \mathrm{LCR}$, and an approach to the characterization of the specific LCR sequence.

\section{Localization of $S 100 \beta$ in brain}

Our in situ hybridization and immunocytochemistry experiments clarify a number of long-standing issues relating to the precise location of $\mathrm{S} 100$ protein in brain. The finding of $\mathrm{S} 100 \beta$ in astrocytes (Bergmann glia) in cerebellum and hippocampus is in agreement with published data (Matus and Mughal, 1975;
Haan et al., 1982). On the other hand, the previously reported presence of $\mathrm{S} 100$ protein in the nucleus of discrete brainstem neurons has been the subject of controversy (Hyden and McEwen, 1966; Ghandour et al., 1981). Because of the nuclear location, a possible role for $\mathrm{S} 100$ protein in the control of gene expression was proposed (Hyden and McEwen, 1966). However, it was not known whether these neurons synthesized S100 protein or the protein was taken up by neurons after being produced and secreted by astrocytes (Hyden and McEwen, 1966). Our results indicate that since both $\mathrm{S} 100 \beta$ mRNA and $\mathrm{S} 100 \beta$ protein are present in selected neuronal populations, these cells actually synthesize $\mathrm{S} 100 \beta$.

The origin of the $\mathrm{S} 100 \beta$-expressing neurons in brainstem nuclei is not known. A presumptive common precursor for neuronal and glial cell lineage has been described in the prenatal mouse hypothalamus (De Vitry et al., 1980). This bipotential stem cell expresses S100 protein and could give rise to both neuronal and glial cell populations in which this protein is found. 


\section{Functional implications of increased $S 100 \beta$ levels}

Our model compares favorably with the other transgenic mouse models derived to study the consequences of aberrant expression of individual genes located on chromosome 21 in humans. In the case of superoxide dismutase, there was no correlation between the number of integrated human gene copies and the observed level of gene expression, and the tissue distribution of the human enzyme differed from that of the product of the endogenous mouse gene (Epstein et al., 1987). Some transgenic mice in that study developed abnormalities in the neuromuscular junctions of the tongue resembling those seen in Down's syndrome subjects (Avraham et al., 1988). These abnormalities were age dependent, and nontransgenic littermates developed similar findings at a more advanced age (Avraham et al., 1988). In the case of the human $\beta$-amyloid protein gene, the transcript of the human transgene represented only a small fraction of the transcript of the endogenous mouse gene in one study (Wirak et al., 1991), and there was no apparent correlation between the integrated human gene copy number and the level of the expressed gene product in the other study (Quon et al., 1991). In the latter study, amyloid deposition was found in the brain of the transgenic mice, but no hehavioral abnormalities were reported.

In contrast, in the present study, the human $\mathrm{S} 100 \beta$ transgene was expressed at high levels in a copy number-dependent and cell-specific manner. The increased immunoreactivity of $\mathrm{S} 100 \beta$ protein in individual astrocytes in the brain of transgenic mice mimics the increased $\mathrm{S} 100$ protein immunoreactivity observed in the brains of Down's syndrome and Alzheimer disease subjects (Griffin et al., 1989). Nonetheless, transgenic mice from each of the four lines did not manifest any obvious behavioral differences or gross pathological abnormalities at autopsy in comparison with their normal littermates. This implies that excessive expression of the $\$ 100 \beta$ gene ranging from approximately 10 - to 100 -fold over normal is generally well tolerated, but does not exclude the possibility that increased levels of $\mathrm{S} 100 \beta$ promote subtle changes in development or behavior that will become apparent in more precise histological and functional assays.

\section{References}

Allore R, O'Hanlon D, Price R, Neilson K, Willard HF, Cox DR, Marks $\Lambda$, Dunn RJ (1988) Gene encoding the $\beta$ subunit of $S 100$ protein is on chromosome 21: implications for Down syndrome. Science 239: 1311-1313.

Allore RJ, Friend WC, O'Hanlon D, Neilson KM, Baumal R, Dunn RJ, Marks A (1990) Cloning and expression of the human S100 $\beta$ gene. J Biol Chem 265:15537-15543.

Arquint M, Roder J, Chia L-S, Down J, Wilkinson D, Bayley H, Braun P, Dunn R (1987) Molecular cloning and primary structure of the myelin-associated glycoprotein. Proc Natl Acad Sci USA 84:600-604.

Ausubel FM, Brent R, Kingston RE, Moore DD, Seidman JG, Smith JA, Struhl K (1987) Current protocols in molecular biology. New York: Wiley Interscience.

Avraham KB, Schickler M, Sapoznikov D, Yarom R, Groner Y (1988) Down's syndrome: abnormal neuromuscular junction in tongue of transgenic mice with elevated levels of human $\mathrm{Cu} / \mathrm{Zn}$ superoxide dismutase. Cell 54:823-829.

Baudier J, Cole RD (1988) Reinvestigation of the sulfhydryl reactivity in bovine brain $S 100(\beta \beta)$ protein and the microtubule associatcd $\tau$ proteins. $\mathrm{Ca}^{2+}$ stimulates disulfide cross-linking between the $\mathrm{S} 100 \beta$ $\beta$-subunit and the microtubule-associated $\tau(2)$ protein. Biochemistry 27:2728-2736.

Behringer RR, Ryan TM, Palmiter RD, Brinster RL, Townes TM (1990) Human $\gamma$ - to $\beta$-globin switching in transgenic mice. Genes Dev 4:380-389.
Blom van Assendelft G, Hanscombe O, Grosveld F, Greaves DR (1989) The $\beta$-globin dominant control region activates homologous and heterologous promoters in a tissue-specific manner. Cell 56:969977.

Burmeister M, Kim S, Price ER, de Lange T, Tantravahi U, Myers RM, Cox DR (1991) A map of the distal region of the long arm of human chromosome 21 constructed by radiation hybrid mapping and pulsedfield gel electrophoresis. Genomics 9:19-30.

Calissano P, Moore BW, Friesen A (1969) Effect of calcium ion on S-100, a protein of the nervous system. Biochemistry 8:4318-4328.

Cicero TJ, Ferrendelli JA, Suntzeff V, Moore BW (1972) Regional changes in CNS levels of the S-100 and 14-3-2 proteins during development and aging of the mouse. J Neurochem 19:2119-2125.

Collis P, Antoniou M, Grosveld F (1990) Definition of the minimal requirements within the human $\beta$-globin gene and dominant control region for high level expression. EMBO J 9:233-240.

De Vitry F, Picart R, Jacque C, Legault L, Dupouey $P$, Tixier-Vidal A (1980) Presumptive common precursor for neuronal and glial cell lineages in mouse hypothalamus. Proc Natl Acad Sci USA 77:41654169.

Duncan AMV, Higgins J, Dunn RJ, Allore R, Marks A (1989) Redefined sublocalization of the gene encoding the $\beta$ subunit of the $S-100$ protein (S-100B) and confirmation of a subtle $t(9 ; 21)$ translocation using in situ hybridization. Cytogenet Cell Genet 50:234-235.

Dunn R, Landry C, O'Hanlon D, Dunn J, Allore R, Brown I, Marks A (1987) Reduction in S-100 protein $\beta$ subunit mRNA in C6 rat glioma cells following treatment with anti-microtubular drugs. J Biol Chem 262:3562-3566.

Epstein CJ, Avraham KB, Lovett M, Smith S, Elroy-Stein O, Rotman $\mathrm{G}$, Bry C, Groner Y (1987) Transgenic mice with increased $\mathrm{Cu} / \mathrm{Zn}$ superoxide dismutase activity: animal model of dosage effects in Down syndrome. Proc Natl Acad Sci USA 84:8044-8048.

Ghandour MS, Langley OK, Labourdette G, Vincendon G, Gombos G (1981) Specific and artefactual cellular localizations of S-100 protein: an astrocyte marker in rat cerebellum. Dev Neurosci 4:66-78.

Greaves DR, Wilson FD, Lang G, Kioussis D (1989) Human CD2 3 '-flanking sequences confer high-level $T$ cell-specific position-independent gene expression in transgenic mice. Cell 56:979-986.

Griffin WST, Stanley LC, Ling C, White L, MacLeod V, Perrot LJ, White CL III, Araoz C (1989) Brain interleukin 1 and S-100 immunoreactivity are elevated in Down syndrome and Alzheimer disease. Proc Natl Acad Sci USA 86:7611-7615.

Grosveld F, Blom van Assendelft G, Greaves DR, Kollias G (1987) Position-independent, high-level expression of the human $\beta$-globin gene in transgenic mice. Cell 51:975-985.

Haan EA, Boss BD, Cowan WM (1982) Production and characterization of monoclonal antibodies against the "brain-specific" proteins 14-3-2 and S-100. Proc Natl Acad Sci USA 79:7585-7589.

Hogan B, LM, Costantini F, Lacy E (1986) Manipulating the mouse embryo: a laboratory manual. Cold Spring Harbor, NY: Cold Spring Harbor Laboratory.

Hyden H, McEwen B (1966) A glial protein specific for the nervous system. Proc Natl Acad Sci USA 55:354-358.

Isobe T, Okuyama T (1978) The amino-acid sequence of $S-100$ protein (PAP I-b protein) and its relation to the calcium-binding proteins. Eur J Biochem 89:379-388.

Isobe T, Okuyama T (1981) The amino-acid sequence of the $\alpha$-subunit of bovine brain S-100a protein. Eur J Biochem 116:79-86.

Kahn HJ, Marks A. Thom H, Baumal R (1983) Role of antibody to S-100 protein in diagnostic pathology. Am J Clin Pathol 79:341-347.

Kahn HJ, Baumal R, Van Eldik LJ, Dunn RJ, Marks A (1991) Immunoreactivity of $\mathrm{S} 100 \beta$ in heart, skeletal muscle and kidney in chronic lung disease: possible induction by cAMP. Mod Pathol 4:698-701.

Kato K, Kimura S (1985) S-100ao $(\alpha, \alpha)$ protein is mainly located in the heart and striated muscles. Biochim Biophys Acta 842:146-150.

Kessler D, Levine L, Fasman G (1968) Some conformational and immunological properties of a bovine brain acidic protein (S-100). Biochemistry 7:758-764.

Kligman D, Hsieh L-S (1987) Neurite extension factor induces rapid morphological differentiation of mouse neuroblastoma cells in defined medium. Dev Brain Res 33:296-300.

Kligman D, Marshak DR (1985) Purification and characterization of a neurite extension factor from bovine brain. Proc Natl Acad Sci USA 82:7136-7139.

Kuwano R, Usui H, Maeda I, Fukui I, Yamanari N, Ohtsuka E, Ikehara 
M, Takahashi Y (1984) Molecular cloning and the complete nucleotide sequence of cDNA to mRNA for S-100 protein of rat brain. Nucleic Acids Res 12:7455-7465.

Labourdette G, Marks A (1975) Synthesis of S-100 protein in monolayer cultures of rat glial cells. Eur J Biochem 58:73-79.

Landry CF, Ivy GO, Dunn RJ, Marks A, Brown IR (1989) Expression of the gene encoding the $\beta$-subunit of S- 100 protein in the developing rat brain analyzed by in situ hybridization. Mol Brain Res 6:251262.

Lewis SA, Cowan NJ (1986) Anomalous placement of introns in a member of the intermediate filament multigene family: an evolutionary conundrum. Mol Cell Biol 6:1529-1534.

Lowry OH, Rosebrough NJ, Farr AL, Randall RJ (1951) Protein measurement with the Folin phenol reagent. J Biol Chem 193:265275.

Marks A, Allore R (1990) S-100 protein and Down syndrome. Bioessays 12:381-383.

Marks A, Law J, Mahony JB, Baumal R (1983) The structural conservation of S-100 protein during evolution: analysis by reactivity with a monoclonal antibody. J Neurochem 41:107-112.

Marks A, Petsche D, O'Hanlon D, Kwong PC, Stead R, Dunn R, Baumal R, Liao S-K (1990) S-100 protein expression in human melanoma cells: comparison of levels of expression among different cell lines and individual cells in different phases of the cell cycle. Exp Cell Res 187:59-64.

Matus A, Mughal S (1975) Immunohistochemical localisation of S-100 protein in brain. Nature 258:746-748.

Moore BW (1965) A soluble protein characteristic of the nervous system. Biochem Biophys Res Commun 19:739-744.

Nakamura Y, Becker LE, Marks A (1983) Distribution of immunoreactive $\mathrm{S}-100$ protein in pediatric brain tumors. J Neuropathol Exp Neurol 42:136-145.

Palmiter RD, Brinster RL (1986) Germ-line transformation of mice. Annu Rev Genet 20:465-499.

Patel J, Marangos PJ (1982) Modulation of brain protein phosphorylation by the S100 protein. Biochem Biophys Res Commun 109: 1089-1093.

Quon D, Wang Y, Catalano R, Scardina JM, Murakami K, Cordell B (1991) Formation of $\beta$-amyloid protein deposits in brains of transgenic mice. Nature 232:239-241.
Sambrook J, Fritsch EF, Maniatis T (1989) Molecular cloning: a laboratory manual. Cold Spring Harbor, NY: Cold Spring Harbor Laboratory.

Selinfreund RH, Barger SW, Pledger WJ, Van Eldik LJ (1991) Neurotrophic protein S-100 $\beta$ stimulates glial cell proliferation. Proc Natl Acad Sci USA 88:3554-3558.

Shashoua VE, Hesse GW, Moore BW (1984) Proteins of the brain extracellular fluid: evidence for release of S- 100 protein. J Neurochem 42:1536-1541.

Stamatoyannopoulos G (1991) Human hemoglobin switching. Science $252: 383$.

Sviridov SM, Korochkin LI, Ivanov VN, Maletskaya EI, Bakhtina TK (1972) Immunohistochemical studies of S-100 protein during postnatal ontogenesis of the brain of two strains of rats. J Neurochem 19: 713-718.

Takahashi K, Isobe T, Ohtsuki Y, Akagi T, Sonobe H, Okuyama T (1984) Immunohistochemical study on the distribution of $\alpha$ and $\beta$ subunits of S-100 protein in human neoplasms and normal tissues. Virchows Arch [Cell Pathol] 45:385-396.

Van Eldik LJ, Staecker JL, Winningham-Major F (1988) Synthesis and expression of a gene coding for the calcium-modulated protein S-100 $\beta$ and designed for cassette-based, site-directed mutagenesis. J Biol Chem 263:7830-7837.

Winningham-Major F, Staecker JL, Barger S, Coats S, Van Eldik LJ (1989) Neurite extension and neuronal survival activities of recombinant S-100 $\beta$ proteins that differ in the content and position of cysteine residues. J Cell Biol 109:3063-3071.

Wirak DO, Bayney R, Ramabhadran TV, Fracasso RP, Hart JT, Hauer PE, Hsiau P, Pekar SK, Scangos GA, Trapp BD, Unterbeck AJ (1991) Deposits of amyloid $\beta$ protein in the central nervous system of transgenic mice. Science 253:323-325.

Zimmer DB, Van Eldik LJ (1986) Identification of a molecular target for the calcium modulated protein S100. J Biol Chem 261:1142111428.

Zimmer DB, Van Eldik LJ (1987) Tissue distribution of rat S-100 $\alpha$ and S-100 $\beta$ and S-100-binding proteins. Am J Physiol 252:C285C289.

Zuckerman JE, Herschman HR, Levine L (1970) Appearance of a brain specific antigen (the S-100 protein) during human foetal development. J Neurochem 17:247-251. 